\title{
迹证 \\ Social Capital Analysis of the Engagement Culture Towards Reducing IMRs and MMRs: A Study of the Pandalungan Community
}

\author{
Farida Nurani $^{1}$, Mardiyono ${ }^{2}$, Bambang Supriyono ${ }^{3}$ and Andy Fefta Wijaya ${ }^{4}$
}

\begin{abstract}
Engagement culture is very common in our society, especially in the Pandalungan community. Through engagement can trigger early marriage for both brides. For prospective brides, if it is still too early, generally they get married after graduating elementary school, around the age of 12-13 years, then pregnancy occurs, then this can lead to the next problem. Often expectant mothers are pregnant and too young. They will have a high risk of being unable to give birth normally and safely. Many high-risk birth events trigger the death of both the mother and the baby. Through social capital analysis, this research explores the details of the problem of maternal and infant mortality rates, where there are norms, trust and networks formed in the engagement culture of the Pandalungan community in Jember.
\end{abstract}

JEL classification: I14, I32

Keywords: Social Capital; IMR and MMR

\footnotetext{
${ }^{1}$ Doctoral Student of Faculty of Administrative Sciences, Brawijaya University. farida_fia@ub.ac.id

${ }^{2}$ Faculty of Administrative Science, Universitas Brawijaya

${ }^{3}$ Faculty of Administrative Science, Universitas Brawijaya

${ }^{4}$ Faculty of Administrative Science, Universitas Brawijaya
} 


\section{Introduction}

Pandalungan ${ }^{5}$, namely the Madurese who lived in the land of Java with acculturation of Madurese culture which had been mixed and compounded with Javanese culture and developed in the long term. Their children and grandchildren still preserve even the developing culture. One culture that is inherent in this society is the culture of "Bakalan" or "engagement". In the Madurese Community, the long-term engagement ${ }^{6}$ of their children has become commonplace. Engaging their children with other families who are considered suitable and suitable for their children is a good thing. Selected to choose a partner from an important and appropriate family in Islam.

If the age of the daughter suggests that she has reached "baliq" (menstruation), but has not yet been engaged, then it is considered as inappropriate or unkind parenting. To avoid this kind of community gossip, parents often rush to get their child to the family of anyone who wants to. This is where the cycle of poverty begins again.

This engagement culture leads to engagements between children who are not sufficiently mature to be engaged for marriage. Where a child is still in elementary school and when some are still toddlers. Why does this happen? Is it because of poverty, or because of longstanding cultural customs?

Usually, the engagement is done within the scope of the family. It is intended that the inheritance of their ancestors does not come out of the scope of his extended family. Besides starting from having good friends who are considered suitable to be tied into his family, both from among his extended family or other people outside his extended family. Starting from a match between these parents, they agreed to tie the good kinship by

\footnotetext{
5 This engagement culture is widely found in East Java in the horseshoe area, which covers the Madura island region, Pasuruan Regency and City, Probolinggo Regency, Lumajang Regency, Jember Regency, Bondowoso Regency and Situbondo Regency. The region is a Madurese tribe that has settled for a long time with a thick Madura culture which then blends with the Javanese culture and gives rise to a mixed culture that is often called the Pandalungan Society.

${ }^{6}$ Engagement Culture

Engagement culture is a tradition handed down by the Madurese predecessors. This is still held firm by the Madurese community even though they have left the Madurese native village and live on other islands such as Java. There are several reasons why the engagement culture is still maintained:

a. Islamic Religious Orders to get married soon. If someone has a desire to build a home and to avoid sinning, then he asks to get married. Apart from that getting married will be preferred for adults. As is known, that's the Madurese community known to be devout in religion.

b. Strengthening friendship relations. One way to strengthen the relationship between the two parties became more harmonious

c. Spread the Religion. As for migrants who are invited as propagators of ancient religions, they set themselves up or one of the family members with native people. With this arranged marriage, it is hoped that they will easily invite the people around him to embrace the religion he brings.

d. Streamlining business affairs or coordination. For business people who are very ambitious to develop their business, they are targeting business partners who are likely to support the business.

e. Improve social status. One effort to improve the engagement is to get a partner from a good family, so that it will improve their social status in the eyes of the community.

f. Improve Heredity. The purpose of marriage is to celebrate the wedding celebration. Through this engagement, it is expected to be better received
} 
getting their children engaged. It doesn't even matter even if their children are underage. Well, this becomes the base of the next problem, because when their children just pass their infancy, they already have a potential partner. Often these pairs of children meet and engage in social activities. This is often done because parents of both parties already know each other's relationship and are considered to have given their blessing to the relationship, only waiting for the time to formalize the relationship in a legal marriage.

However, it turns out that a lot of reality happens that the engagement or "Bakalan" that triggers early marriage. Whereas early marriage, as we know, often results in high risks to health for expectant mothers. Many incidents of death of pregnant women with vulnerable and high-risk ages are too young or too old.

Based on data from the Central Statistics Agency in 2012, East Java recorded a high MMR and MMR. Infant Mortality Rate (IMR) (per 1,000 live births) reaches 28.31, while the MDG's target for IMR in 2025 is 15.5. On the other hand, the Maternal Mortality Rate (MMR) in East Java in 2012 was still 97.43, while the MDG target was 74 (per 100,000 live births) (BPS, 2012). This means that there is still a difference of 12.81 for IMR and a number of 23.43 for MMR. Achieving this ideal figure requires a strong effort from the regional government, in collaboration with relevant agencies, and active community participation.

The earliest reasons for poverty arose, but various schemes of poverty alleviation financing programs in breaking the poverty chain have not been able to provide a complete solution. Babies born to parents' families in poor households are more likely to be born with low weight, under 2500 grams. Many studies conclude that low birth weight is associated with many other health problems in its infancy. The intensity of poverty with education and health problems can lead to new problems: a vicious cycle of poverty. Children born from poor families will have a low quality of human resources. As adults and enter the labor market, they are also more likely to compete and get stuck in lowincome jobs. Finally, they cannot escape from poverty like their parents.

\section{Literature Review}

\section{a. Social Capital}

Based on the theory of social capital, Fukuyama (2017) states that social capital is a capability which arises from the trust in a community. Social capital can be defined as the source (resource) arising from the interaction between people in a community. Institutionally, the interaction can be born at the time of the vision and goals of the organization have in common with the vision and goals of other organizations. People who have high social capital tend to work in mutual cooperation, feel safe to speak and able to cope with differences. Conversely, people who have low social capital will appear suspicions of each other.

According to Putnam, social capital is:

"Complexly conceptualized as the network of associations, activities, or relations that bind people together as a community via certain norms and psychological capacities, 
notably trust, which are essential for civil society and productive of future collective action or goods, in the manner of other forms of capital. (Putnam, 1993:34-42) ${ }^{7}$

\section{B. Education and Women}

Maternal education is vital to the health of children or families. The absorption of diverse and different information is strongly influenced by a mother's education level. The background of formal and informal education will be very influential in all aspects of the life of the mother from the aspect of her thoughts, feelings and actions. The higher the education level of a mother, the higher the basic ability of the mother in taking care of the baby starting from the process of pregnancy to the provision of breast milk (ASI). The level of education can underlie a mother's attitude in absorbing and changing the information system about breast milk. Where breast milk is the main and best food for babies aged $0-2$ years.

It is very concerning that more than $33 \%$ of mothers in Indonesia did not complete primary school (Jawa Timur Dalam Angka Terkini Tahun 2012-2013, BPS, 2012)[2]. Of course, this is very influential on the high IMR and MMR. A very low level of maternal education contributes to a very poor maternal and infant mortality rate. How can a mother know the nutrients they need during pregnancy if they have never heard the name of folic acid and choline? Yet both are very vital during the mother's pregnancy.

Moreover, the women in Jember, especially Sukowono sub-district do not have high motivation to continue school to a higher level, because they have to run to the kitchen to cook, to serve their husbands and to go to the well to get water, or they have to take care of cleanliness for their family members. They will only continue to deal with domestic work, which they say does not require a high level of schooling.

\footnotetext{
${ }^{7}$ Of the various reasons for the engagement, it was intended to be good but in fact there was a false assumption about the initial purpose of the matchmaking. Ironically, they assume that when they have been betrothed to their potential partners, then they feel they have received the blessing to always be alone anywhere freely, even though in religion it is strictly prohibited. This has injured the engagement culture.
}

In addition, early marriage also triggers the death of mother and baby. Young age for women, will have a high risk in the birth process. This is because the womb of a young woman is not enough to be fertilized, so prone to bleeding that could result in death.

If there are problems in a newly married family, usually parents or in-laws are still involved in decision making in the new family. This happens because the bride and groom from the results of this early marriage are still very young and have not been able to finance all the daily needs in their new lives, so they still depend a lot on their parents.

If there is a problem in the process of the birth of their baby, then the role of parents is crucial in the decision making process. As is the case with the writer who saw in Sukowono, that there had been bleeding in a woman's pregnancy from an early marriage, but the first aid was not from the health workers from the puskesmas, but what was called was a dukun beranak in their village. Cases of bleeding for pregnant women are very at risk for death. Especially because of the late help, the delay in decision making by the family in determining first aid.

Most people in Sukowono, especially in remote areas, still rely heavily on the help of TBAs in childbirth. Decision-making is done by parents or in-laws, with many considerations, both economically, health insurance and choice of place of delivery. All of this makes the decision making slow, while young mothers who are experiencing bleeding are unable to survive and die with the foetus they are still carrying. 
Many obstacles found by health workers in the area. Such as some beliefs about pregnant and delivering mothers that backlash the efforts of reducing mother and infant mortality rate. This significantly affects the low health quality of society in Jember Regency. Especially in Sukowono sub-district, as the subject of research, has given a big number of mother and infant's low health quality seen from both mother and infant mortality rates.

The other obstacles, such as maternity with high risk. Meaning the women are older, but still pregnant. Most of them did not use contraception to manage their pregnancies. Often they have grandchildren, but they are still pregnant. This makes them embarrassed to monitor their pregnancy at the health clinic, so for a young pregnancy, there is an undetectable high risk. This is a matter of concern, because maternal and infant mortality cases are more likely to occur to those at high risk by never having maternal and neonatal health check-ups at a health centre.

From the interviews, it can be concluded that pregnant women who are older but still productive will have a high risk of maternal or infant mortality, the quality of maternal and infant health is also at stake. Although not generally leading to death, usually the birth process will experience problems, such as premature birth, bleeding, until death. This adds to the long list of low quality maternal and infant health problems.

\section{c. Pandalungan Community}

Culturally, the Pandalungan community is a hybrid society, that is, a new cultured society due to the mixing of two dominant cultures. In the context of the East Java "horseshoe" area, pandalungan culture is a mixture of two dominant cultures, namely Javanese culture and Madura culture. In general, Pandalungan people reside in urban areas. Administratively, the Pandalungan cultural area includes Pasuruan, Probolinggo, Situbondo, Bondowoso, Jember, and Lumajang Regencies

\section{III.Research Method}

The type of research used in this study is a cultural descriptive- qualitative approach. Through the research design used, the researcher is collecting data and information in a holistic manner to the actors involved and doing forum discussion group with 32 participants in Sukowono sub-district for reducing the Mother and Infant Mortality Rate in Jember regency. By using Spreadly data analysis, it is expected to be able to get cultural findings (Sugiyono, 2012).

\section{Results and Discussion}

\section{Analysis of Social Capital in Engagement Culture}

A Norm is one parameter of social capital. Norms are divided into understanding, values, hopes and goals done by people. Norm is a source to shape and form moral. Role of social capital in shaping village and urban society based on the norm is as follows:

Norms of existing kinship. Sukowono community kinship is very culturally important and ties are strong. They feel a struggle to live as settler. Despite the fact they have been 
more than two generations live there. Sense of belonging Sukowono community is very strong. ${ }^{8}$

The Engagement Norms. In Jember, Sukowono sub-district, the engagement or matchmaking culture is often referred to as "Bakalan". In dealing with this society, a match is evaluated in several ways. Families usually try to maintain relationships and friendships through their children by reaching a marriage agreement between their children. Another motive for matchmaking is keeping the family's inheritance. But often their children have not met the criteria for matchmaking efforts. For example, their children are still too small or not old enough to be married, the parents have done matchmaking since the beginning. If they have been married to their fiancée, they will automatically stay with their parents or in-laws. The children's everyday needs will be provided by the parents. Sometimes, young pregnancies arise as a result of affairs with parents or parents in law.

Some reasons for engagement (Bakalan) in Jember Regency (interview with residents Sukowono Feb 2016):

1. Has become a culture in society, so if a family does not follow it, they will be ostracized by the surrounding community.

2. The woman's parents have a moral burden or will feel ashamed if their daughter has not become engaged. Because of this will be the gossip material of the surrounding community.

3. The desire of parents to immediately have a grandchild. Having a grandchild is a source of pride and happiness for parents, prospective grandmother(s) or grandfather(s).

4. To keep the inheritance of parents or in-laws. Usually, engagements for this purpose are done through the family line.

Actually, this engagement culture could be good if done in the right way. If not for the premature age of engagement and childbearing. Because of the premature age of the participants, the marriage often happens with the falsification of the age of the bride and groom in the filing of the marriage file. The falsification of ages in identity cards (KTP) and family cards (KK) becomes the usual thing done by parents and is tolerated by the officers in the village.

Norms of Pregnancy and Birth. When a woman is said to be pregnant, the posyandu cadre will immediatelytend to find out. Because of a woman's pregnancy, health center services through cadres will often make contact and look after the condition of the pregnant woman. They will invite the pregnant women to be diligent to check their pregnancy health at the health service center. Even if pregnant women cannot come to the health center, posyandu cadres will come to pregnant women and check the condition of pregnant women at home. Before the posyandu cadre actively assisted pregnant

\footnotetext{
${ }^{8}$ Pandalungan community highly values the value of togetherness and strong brotherhood. These values are still strongly preserved among the Madurese extended family.
} 
women, the Sukowono community held a cultural belief that women pregnant for less than three months were prohibited from leaving home. It was believed that if the pregnancy was not yet three months advanced and the expectant mother left her home, that miscarriage would occur. But this kind of belief is no longer widely held because of the strong socialization about the health of mothers and babies from the public health center.

Trust.

Related to society's trust toward the government or health workers in decreasing IMR and MMR, especially in Sukowono sub-district can be categorized as good, as seen in the interview of Sukowono's sub-district chief in the following 9 .

\section{Networking}

A form of networking is one parameter of social capital. Networking will facilitate the communication process and interaction that stimulate trust and strengthen cooperation. Social networks are a valuable asset in dealing with humans. Through the network, able to glue a person to connect directly with others in order to be mutually beneficial.

Through social networks, resource allocation does not have to go through a network of tiered structures, but through individual networks that are more horizontal. Social networks occur because of the inter-linkages between individuals within a community. In groups or communities are usually formed on the basis of interests, goals and desires together.

Pendalungan society is formed on the basis of the similarity of lineage, common beliefs and ethnic equality. The similarity of belief in the religious dimension produces high cohesion but a narrow range of networks and trusts. However, if an organization is formed on the basis of a common goal and orientation with the management characteristics of a modern organization, it will have a high level of participation.

Basically, social capital is a collaboration built to achieve the goal. Cooperation is created when there is a social interaction relationship to produce cooperation network, social exchange, mutual trust and formed values and norms in the interaction relationship.

\section{Social Institutions}

The impact of early marriage on IMR and MMR. The socio-economic conditions of the community mostly fall on poor families. For families who believe in this culture of engagement and early marriage, that tends to produce new poverty. Most of the engagements are among their own relatives, that is still their big family. This is done because of the desire to keep their inheritance so as not to allow inheritance to fall to non relatives.

\footnotetext{
${ }^{9}$ Trust is the main capital in maintaining the values of brotherhood, togetherness and sense of belonging, so that the value of Trust is strong in Social Capital in the Pandalungan Sukowono community
} 
Table of Engagement in Social Capital Analysis

\begin{tabular}{|c|c|c|c|}
\hline No & $\begin{array}{l}\text { Social Capital } \\
\text { Aspect }\end{array}$ & $\begin{array}{l}\text { Community cultural and } \\
\text { behavioral analysis }\end{array}$ & Impact \\
\hline 1 & $\begin{array}{l}\text { Trust, Honesty, } \\
\text { Egalitarian } \\
\text { Attitude }\end{array}$ & $\begin{array}{l}\text { a. Strengthening personal } \\
\text { relationships within the } \\
\text { community } \\
\text { b. The highest level of Trust is the } \\
\text { formation of community and } \\
\text { cooperation (Putnam, 2000, 20- } \\
\text { 21) }\end{array}$ & $\begin{array}{l}\text { 1. Perpetuated through Engagement culture } \\
\text { 2. Violates the age requirement of marriage } \\
\text { 3. Manipulate the age on the ID card } \\
\text { 4. In early marriage the prospective mother's } \\
\text { uterus is not ready, triggering bleeding until } \\
\text { death during pregnancy and childbirth } \\
\text { 5. Age of early marriage triggers divorce thereby } \\
\text { increasing the number of widows and the } \\
\text { number of poor people } \\
\text { 6. Believe that new mothers should not eat protein } \\
\text { foods, such as fish, chicken and meat because it } \\
\text { is considered will slow the healing of wounds } \\
\text { during childbirth. } \\
\text { 5o breastfeeding is not qualified } \\
\text { 8. There is malnutrition for breastfeeding mothers } \\
\text { due to iron deficiency }\end{array}$ \\
\hline 2 & $\begin{array}{l}\text { Network } \\
\text { ((participation, } \\
\text { reciprocity, } \\
\text { solidarity, } \\
\text { cooperation) }\end{array}$ & $\begin{array}{l}\text { a. Build community participation } \\
\text { b. Building cooperation among } \\
\text { members within the community } \\
\text { c. Reciprocity is available but } \\
\text { limited } \\
\text { d. Stimulate the emergence of high } \\
\text { solidarity } \\
\text { e. High cohesiveness but occurs in } \\
\text { narrow space }\end{array}$ & $\begin{array}{l}\text { 1. In the affairs of agriculture or trade they can help } \\
\text { each other because it has become a big family. } \\
\text { 2. Make it easier to build cooperation in large } \\
\text { families. } \\
\text { 3. Cooperation is established on the basis of equality } \\
\text { of lineage, religion and ethnicity. } \\
\text { 4. There are resource exchanges but are limited to } \\
\text { communities only. } \\
\text { 5. Solidarity between members is very strong but the } \\
\text { scope is narrow } \\
\text { 6. Equality in community is balanced with } \\
\text { solidarity. }\end{array}$ \\
\hline 3 & $\begin{array}{l}\text { Norm (shared } \\
\text { values, norms and } \\
\text { sanctions, rules) }\end{array}$ & $\begin{array}{l}\text { a. Exclusivism. It happens only to } \\
\text { those who understand the shared } \\
\text { values } \\
\text { b. Trying to preserve the culture of } \\
\text { Madurese living in Java } \\
\text { c. Created and supported by } \\
\text { socialization and sanctions } \\
\text { (Putnam 1993, in Hauberer } \\
\text { '2011: 56) }\end{array}$ & $\begin{array}{l}\text { 1. Exclusivism can hamper networking processes, } \\
\text { because different ones do not belong to their } \\
\text { class. } \\
\text { 2. Always get involved in their children's household } \\
\text { affairs } \\
\text { 3. Justified to be involved in making decisions in the } \\
\text { families of their children } \\
\text { 4. Do not educate children to be independent, so } \\
\text { unable to make decisions for his family } \\
\text { 5. A strong family bond will make the sanctions } \\
\text { weak if there is a falsification of age in marriage } \\
\text { 6. No sanction to Manipulate the age on the ID card }\end{array}$ \\
\hline
\end{tabular}

Starting from this arranged marriage then triggers for immediate marriage for their children. In fact, often, this matchmaking effort is done when their children are still toddlers. When children start teenagers, around elementary school graduation, parents have started to notify their prospective fiancé. Mostly for girls, once they graduate from elementary school, they are not willing to go to a higher school because they will get married soon. 


\section{$V$ Conclusion and Recommendation}

In conclusion, the engagement norm that triggers early marriage and thus carries a high risk of maternal and infant death in Jember, sub-district Sukowono is still strong. Because of the prospective mother's womb is too young and not ready to bear a baby. This triggers the occurrence of problems in the process of birth. The emergence of Trust is strengthened through engagement culture. This is still happening in sub-district Sukowono. Networking in the sub-district Sukowono communities should be able to develop optimally because there are elements of trust. Trust has been formed by the existence of strong networking that occurs in large families that they establish in engagement and other kinship.

It is recommended that the active role of the education office should be to motivate female students (in particular) that higher education for women is important for the welfare of their families later. Also important is the dissemination of information about the negative effects of early marriage. Socialization of early marriage delays must be carried out by all government agencies that have the task of reducing the MMR and IMR. Finally, in order to continue to strengthen networking among local government institutions with community participation through various joint activities starting from the regional level to the rural level.

\section{References}

BPS, 2012, Jawa Timur Dalam Angka Terkini Tahun 2012-2013. BPS East Java

BPS, 2012, Jawa Timur Dalam Angka Terkini Tahun 2012-2013. BPS East Java

Fukuyama, Francis, 2017, The Great Disruption: Human Nature and the Reconstitution of Social Order. Free Press. New York

Putnam, Robert D,1993, The Prosperous Community-Social Capital and Public Life, American Prospect 